\title{
Competitive priorities in the urban mobility sector
}

Estela Tieko Oshiro ${ }^{1}$, Federal University of São Carlos, Department of Production Engineering, Sâo Paulo, Brazil

Márcia Regina Neves Guimarães ${ }^{2}$, Federal University of São Carlos, Department of Production Engineering, Sâo Paulo, Brazil

Felipe Ferreira de Lara ${ }^{3}$, Federal Institute of Education, Science and Technology of São Paulo, Department of Industry, Sâo Paulo, Brazil

\section{RESUMO}

Objetivo - A pesquisa tem por objetivo identificar as prioridades competitivas adotadas por uma empresa que atua no setor de serviços em mobilidade urbana e analisa práticas e estratégias que reforçam as prioridades adotadas.

Metodologia - Estudo de caso exploratório a partir de uma abordagem qualitativa, por meio de entrevistas semiestruturadas com quatro atores relevantes ao desenvolvimento do problema de pesquisa.

Resultados - Foi possível observar que as tecnologias para mobilidade permitem a implementação de inovações baseadas na percepção do desejo do cliente que, no caso desta pesquisa, teve a qualidade como elemento central. Um ponto central identificado foi o fato de a empresa em estudo utiliza a inovação na customização de produtos para manter níveis competitivos de qualidade e diferenciação por meio de inovações em serviços. Por outro lado, existe uma restrição em relação à dificuldade em controlar os níveis de serviços executados pelos motoristas.

Contribuições - A pesquisa contribui para um melhor entendimento das necessidades do cliente no setor de serviços em mobilidade urbana, e de modo a garantir maior satisfação do cliente e melhorar o nível de qualidade na prestação dos serviços, resultando em desempenho e vantagem competitiva para empresas do setor.

Palavras-chave - Prioridades competitivas; qualidade; serviços; inovação.

\section{ABSTRACT}

Purpose - This study aims to identify the competitive priorities adopted by companies that operate in the urban mobility services sector and analyzes practices and strategies that reinforce the priorities adopted.

Design/methodology/approach - An exploratory case study using a qualitative approach, through semi-structured interviews with four participants, was used to develop the research problem.

Findings - It was found that technologies used for mobility allows the implementation of innovation based on the perception of the customer's wants, which, in the case of this study, seemed like the central element. The central point identified was the fact that the company being studied used innovation when customizing products to maintain competitive levels of quality and distinction through service innovations. On the other hand, there is a restriction which had a greater impact, which is due to difficulty in controlling the levels of services performed by drivers.

Originality/value - The study contributes to a better understanding of the customer's needs in the urban mobility services sector, and in order to ensure higher customer satisfaction and improve the level of quality in the supply of services, resulting in a good performance and competitive advantage for companies in the sector.

Keywords - Competitive priorities; quality; services; innovation.

1.tieko.estela@gmail.com, https://orcid.org/0000-0003-4525-8737; 2. mrng@ufscar.br; http://orcid.org/0000-0001-8471-3216 3. Rua Zélia de Lima Rosa, 100 - Portal dos Pássaros, Boituva - SP, 18550-000, fflara@ @ifsp.edu.br; https://orcid.org/0000-00019093-8454

OSHIRO, E.T.; GUIMARÃES, M.R.N.; LARA, F.F. Competitive priorities in the urban mobility sector. GEPROS. Gestão da Produção, Operações e Sistemas, v. 15, n.4, p. 115 - 133, 2020.

DOI: http://dx.doi.org/10.15675/gepros.v15i4.2696 


\section{INTRODUCTION}

The concept of competitiveness has changed over time, becoming a strategic role in the management of the business and becoming fundamental for the survival of organizations (PRAJOGO; MCDERMOTT, 2011; WECKENMANN; AKKASOGLU; WERNER, 2015; JAYARAM; XU, 2016; MIKAMI, 2018) or even for the growth of a city (SCHIAVONE; PAOLONE; MANCINI, 2019). In order to reinforce the importance of quality in service delivery, Bettencourt, Brown and Sirianni (2013), Cai and Yang (2014) and Roy, Sreejesh, and Bhatia (2019) emphasize that society is constantly changing and, as a consequence, organizations also change to adapt to the new environment and meet your goals.

In a competitive world, the success of a company depends heavily on the competitive strategy adopted. As the competitive strategy is supported by the functional strategy, each of the functional areas is fundamental to the success of the organization (LIN; TSENG, 2016). Among these areas, we highlight the production function due to the scope of its activities in the organizational context (GARTNER, GARCIA, 2005).

When dealing with production function, the topic of production strategy is addressed. Scur and Heinz (2016) indicate that this strategy dictates what activities the organization needs to perform efficiently and effectively in order for the final objectives to be achieved. The production strategy can be divided into content and process. Voss (1995), Swink and Way (1995) and Voss (2005) classify the process in strategy formulation and implementation, while content refers to decision areas and competitive priorities.

For Hung, Hung and Lin (2014) and Kathuria et al. (2018) competitive priorities express how the company positions itself in the market and, in addition, have the function of supporting corporate strategy. From this definition, it is noticed that the competitive priorities are an essential element for the performance and success of the organizations.

Thus, the present study aims to identify the competitive priority (s) and analyze practices and strategies adopted regarding quality management that reinforce the priority (s) practiced in a given organization and the decisions taken in terms of these priorities. The present research is based on a qualitative approach used in the case study of a service provider in urban mobility located in the city of São Paulo, Brazil, one of the most chaotic transits in the world. 
The present research is divided in a following topic related to the theoretical reference, which covers the concepts involved of competitive priorities, complementing with the quality management and aspects of the service sector. With a third topic, the research method is presented to further develop the research results and the respective debates. Finally, we present the final considerations regarding the study.

\section{LITERATURE REVIEW}

\subsection{Competitive Priorities and Decision Areas}

The content of the production strategy is the interaction between the competitive priorities of the operation and the decision areas, which determine the implementation of resources (VOSS, 1995, 2005, SLACK; LEWIS, 2008). It can be said that the content of the production strategy is the result of the strategic reconciliation between what the market demands, represented by the performance objectives and the production resources, translated into decision areas (SLACK; LEWIS, 2008).

Maia, Cerra, Alves Filho et al. (2009) and Kathuria et al. (2018) emphasize that competitive priorities reflect the needs of the competitive strategy and point out the objectives to be achieved by the productive system. And for these goals to be achieved, we need to develop a pattern of actions related to a set of decision areas.

The production function is organized from the definitions of competitive priorities and then takes the structural and infrastructural decisions to model its operations. These structural and infrastructural decisions make up the decision areas. Structural influences project decisions, while infrastructural influences an organization's workforce and planning, control, and improvement activities (JABBOUR, 2010).

For Hayes, Pisano and Upton et al. (2008), structural decisions require substantial capital investment and, after being made, are difficult to change or reverse. Infrastructure decisions, while not demanding high investments, needs great efforts for formulation and implementation, and are also difficult to change. The structural decision areas are classified into capacity, vertical integration, installation and technology decisions. As far as infrastructure decision areas are concerned, they include human resources, production 
planning and control, quality system, organization, new product development, metering and reward systems, and resource allocation and capital budgeting.

From another perspective it is a mistake to categorize the decision areas as being entirely structural or entirely infrastructural. In fact, all decision areas have structural and infrastructural implications. The best way to represent these decisions is to consider a spectrum that covers the structural part and the infrastructural portion (SLACK; LEWIS 2008; HAYES et al., 2008).

In this sense, competitive priorities are fundamental to the production strategy, as they indicate which functions production must perform with excellence. In this way, production activities must be defined in capacities so that companies can compete with their business strategy (BOYER; LEWIS, 2002; WARD; McCREERY; ANAND; 2007).

Diaz-Garrido, Martín-Peña and Sanchez-López (2011) define the performance objectives as the grouping of competitive factors, which, in turn, are the dimensions that define the market position of how the company wishes to compete. Competitive factors are related to the perceptions that a customer may have about a given product or service and the company must choose which competitive priorities should receive the most investment of time and resources.

Jabbour (2010) concludes that competitive priorities are a way of translating customer needs to be met by the company in terms of performance targets for the production function. For Cai and Yang (2018), developing it is the first step in a company's manufacturing strategies. With priorities firmly established in place, the company develops a set of plans that is operationalized through the programs, processes, and technologies to be sought to realize those plans. Together, competitive priorities and action plans constitute the company's manufacturing strategy, which ultimately affects the operational capacity and results of the business.

Maia et al. (2009) points out those vary according to different circumstances and company strategy. In the literature we observe different definitions of it. Slack and Lewis (2008), for example, classify in five: quality, flexibility, speed, reliability and cost. Alves Filho, Pires and Vanalle (1995), Ward et al. (2007), Jabbour (2010) and Silva, Santos and Castro (2012); Cai and Yang (2018) list four: cost, delivery, flexibility and quality.

The authors Bouranta and Psomas (2017) define cost such as the ability of a company to effectively manage the cost of production; delivery, such as meeting the deadline and with 
a short production cycle; flexibility, such as the ability to respond quickly to changes and quality, as the focus on high compliance with the product specification.

There is a discussion in the literature about innovation as a competitive priority. There are studies that put innovation as a synonym for flexibility. Dangayach and Deshmukh (2006) and Theodorou and Florou (2008), for example, put innovation as the ability to introduce new products (mainly) and new processes, which is similar to other works such as those by Grobler and Grubner (2006) and Kathuria et al. (2010), which address the concept of flexibility as the rapid introduction of new versions of existing products or entirely new products. However, recent studies like Lin and Tseng (2016) and Krammer (2017) have placed innovation at a prominent level among the competitive priorities.

\subsection{Quality management}

The great challenge of organizations is to remain competitive in the face of economic, political, social and labor relations changes. This context forces the reflection on how the management of the organizations is being carried out. They are the organizations that value their services, seek effective management and value the needs of their clients that prove to be enduring in the market (MIRANDA; GALOTTI; MIRANDA, 2016).

The concept of quality has changed over time. It started with minor improvements in the operations of manufacturing processes and then became one of the central elements for the survival of organizations. These changes occurred due to the increasing competition of the environment in which these organizations operate (CARVALHO; PALADINI, 2013). It has come to be seen as a strategic weapon to combat loss of profitability or market share and it is within the context of a high level of nonconformities and the risks of company reputation, market share and profitability (OLIVEIRA, 2003).

According to Carvalho and Paladini (2013, p.90), quality management consists of a set of coordinated activities to direct and control an organization with regard to, including planning, control, assurance and level of services improvement.

So, it has as basic objective to propose strategies to reduce waste and rework through an educational process that makes people aware that this action is a commitment of all of the organization and it aims to develop means and methods for winning and maintaining its 
customers, understanding that its employees, management and suppliers are the first customers to be loyal customers (MIRANDA et al., 2016).

Quality or its absence influences the whole chain, from the supplier to the final consumer. Otherwise, developing an organization that can achieve requires the effort of everyone. To achieve it, the environment must first be conducive to this, followed by knowledge and, then, the collaboration of everyone for implementation. When these steps are successful, the organization starts to satisfy consumers and, consequently, acquires a competitive advantage (HEIZER; RENDER, 2001).

Quality management, governed by a set of resources, rules and procedures, has the function of serving the stakeholders and helps to create successful strategies of differentiation, low costs and customer responses, elements critical to competitive success. The perception of it as a competitive criterion, capable of providing competitive advantage, has brought some theorists from the area of strategy and administration to the field, such as Garvin, who discussed the strategic impact of it.

In this sense, in order to meet quality requirements, management practices have evolved over time, in addition to being of greater importance due not only to the market demand, but also to the pressure for delivering high results (WECKENMANN; AKKASOGLU; WERNER, 2015).

Oliveira (2003) emphasizes that quality, from the point of view of strategic management, is defined in relation to competitors and not to internal standards. It is the customers that determine whether a particular product is acceptable or not. In this way, the specifications started to occupy a secondary role, being the main activity the identification of the needs of the customers.

According to Carvalho and Paladini (2013), this strategic perspective considers quality as a survival factor for organizations, in which it is elevated to the category of competitive differential of organizations, makes decisions about and adopts a vision of the future on the issue, considering several scenarios.

Such an approach extends what has traditionally been understood as quality and increases its importance, responsibility and demand for decision making on the ways to plan and develop its conceptual and practical implementation in organizations. 


\subsection{Service Sector Innovations}

According to Jayaram and $\mathrm{Xu}(2016, \mathrm{p} .3)$, "the literature on the competitive priorities of the manufacturing is more developed than that of the service." In addition, Prajogo and Mcdermott (2011) emphasize that the literature only addresses what the service sector is not, that is, it is not tangible, non-stockable and non-transportable. This fact may be associated to the characteristics of the service (intangibility, heterogeneity, inseparability, perishability), which makes its study more difficult.

There are some differences between the service sector and the manufacturing sector, identified by Bouranta and Psomas (2017): the manufacturing produces goods with tangible and specific characteristics and, in addition, manufacturing can be divided into production and consumption. On the other hand, it was not possible to store services and production and consumption occur simultaneously. Another characteristic of services is heterogeneity, which makes it difficult to standardize the service (BOURANTA; PSOMAS, 2017).

According to Bettencourt et al. (2013), Snyder, Witell, Gustafsson et al. (2016), Witell, Snyder, Gustafsson et al. (2016) and Ryu and Lee (2018), as service economics dominates more and more companies, the generation of product innovation associated with services has been improving not only to retain customers but also to promote competitive advantage over competitors. Successful approaches to innovation in services are relevant in stagnant economies, especially where declining spending leads to a decline in economic activity and intensify competition between firms.

Snyder et al. (2016) and Witell et al. (2016) suggest that service innovation creates value for clients, employees, entrepreneurs, alliance partners, communities through new and/or better service offerings, service processes, and business models. Consequently, by adding service to innovation, such action introduces new or alternative perspectives to the business.

Bettencourt et al. (2013) further reinforces that in today's challenging business environment it is no longer enough to just deliver quality service to customers in a timely manner. Instead, companies need to find ways to innovate new service offerings that bring differentiated advantages. On the other hand, this type of innovation is not easy to reach, as the nature of the service activity is intangible and the active participation of the customer in 
the generation of supply is uncertain, the process of innovating in services becomes a challenge.

\section{METHODOLOGICAL PROCEDURES}

The qualitative research aims at the study and analysis of the empirical world in its natural environment and highlights the direct contact of the researcher with the environment and the situation studied. In other words, this is the direct source of data and the researcher can be seen as the instrument of observation, selection, analysis and interpretation of the data collected.

The choice of the case study as a procedure method was due to what Fonseca (2002) and Miguel (2007) define as a research of a well-defined unit, which aims to explore the how and why of a given situation, seeking expressive characteristics and unique, from their perceptions.

The case studies can be classified according to the content and final objective, as exploratory, explanatory or descriptive. In this research, the purpose of the case is descriptive, because it seeks to relate competitive priority and quality management, issues together little present in the literature, seeking to provide greater familiarity with the problem to make it more explicit or to help build hypotheses.

According to Yin (2001) there are two types of case studies, single or multiple. In the present research, we chose to adopt the unique case study that, according to Yin (2001), is ideal when one wants to determine if the propositions of a theory are valid or to research a rare case that does not have similar situations to compare or when the case is revealing and the researcher has access to information that was not previously available. In this sense, we seek to analyze the relationship between quality management and the competitive priorities adopted by the company, based on semi-structured interviews carried out in the selected business unit.

The company in this research is a service provider in the area of urban mobility and technology, which performs the agency of passengers. It is present in the national and international market. The unit analyzed has 140 employees within 9 functional areas and is located in the city of São Paulo. 
The chosen unit, in São Paulo, has the largest operation in the world and is constantly growing. This unit has been working since June 2016 and has emerged as a startup, for presenting an innovative business model and for meeting a market need.

The choice of the unit can be explained from the literature gap on competitive priorities mainly in the service sector involving startups and for the interest in studying a company with a current business model and with strong potential for growth and expansion.

Four interviews were conducted: one with the logistics manager, one with the coordinator, responsible for acquisition and loyalty activities of new drivers, and the other two with logistics associates. The area hierarchy can be defined from top to bottom as manager, coordinator, associate, assistant and trainee. The manager is responsible for five subareas and deals with strategic issues related to company goals. The role of the coordinator is to establish plans to achieve the goals of the area. Associates are responsible for carrying out these plans together with the assistants and trainees.

Each interview lasted about 45 minutes and the results were transcribed and tabulated within less than two days for all interviews in order to capture the maximum amount of information generated.

Based on the research objectives, the script was divided into four blocks. The first one refers to a general characterization of the company and the service provided, the second block addresses the priorities competitive practices, the third to indicators and the fourth to the innovation process in the company.

\section{RESULTS AND DISCUSSION}

The results session is divided into two subtopics: the first one addresses the competitive priority (s) adopted, the characteristics and the service provided by the company; and the second is the quality and innovation promoted by it.

\subsection{Company and service characteristics and Competitive Priorities}

The main product offered by the company is an option of urban mobility through private cars. The unit operates following the B2B2C (Business to Business to Consumer) concept, that is, the company provides a platform for one party to provide the service and the other party to consume it. 
In this way, the growth of customers (passengers) demands the growth of the number of individual micro entrepreneurs (drivers) and the clients can be individuals or legal entities, in the latter case, corporate passengers.

All the interviewees answered that the profile of the passengers clients are, for the most part, women of social class A and B and that they have credit card. In the case of service providers, respondents agree that the majority are unemployed or seeking an alternative source of income and belong to classes $\mathrm{C}$ and $\mathrm{D}$, ranging in age from 30 to 50 years.

Besides the main product, the company offers transport of people by means of taxi and helicopter and the transport of objects. Focusing on the main service, transporting people through private cars, it is possible to customize the action by choosing a few options such as radio station, air conditioning on and door opener.

In relation to the identification of the most important competitive priorities for the company, according to the approach of Alves Filho et al. (1995), Ward et al. (2007), Jabbour (2010) and Silva et al. (2012), Cai and Yang (2018) the results are shown in Table 1.

Table 1 - Competitive priorities of the company in the view of the interviewees

\begin{tabular}{c|c|c|c|c} 
Interviewee/Competitive Priority & Cost & Quality & Delivery & Flexibility \\
\hline Logistics Manager & $\mathrm{X}$ & $\mathrm{X}$ & & \\
\hline Logistics Coordenator & & $\mathrm{X}$ & & \\
\hline Logistics Associate 1 & & $\mathrm{X}$ & & \\
\hline Logistics Associate 2 & & $\mathrm{X}$ & &
\end{tabular}

Source: Prepared by the authors.

For the logistics manager, the competitive priority "quality" is the most stimulated by the company, especially in the sense that all the communication media and the company focus on priority as the essential means of competitive advantage. These means of communication include the campaigns of dissemination of the service, websites, social networks, meetings, trainings and internal and external events. In addition, the logistics manager points out that cost is also a relevant competitive priority, since prices cannot be much higher than competitors because it is a highly competitive market.

In the literature, the company has to choose which competitive priorities its efforts will focus on (BOYER; LEWIS, 2002; WARD et al., 2007) to meet customer needs (JABBOUR, 
2010). This choice has as motivation to serve a niche market that seeks a service with more quality, compared to other competitors, and who are willing to pay a premium price. The "cost" factor is practiced by the company by the fact that the customers are not willing to pay a much higher price than the competitors.

Regarding the role of the main stakeholders in determining the "quality" competitive priority, everyone agreed that the driver is the one who has a high degree of contact with the customer and is responsible for providing a quality service and satisfying the customer, of the logistics area responsible for conducting the training of these drivers. In this way, there is a shared responsibility to develop the competitive priority adopted by the company to compete in the market.

The company has a number of vehicle requirements for quality. Thus, this quality is related to the service offer according to pre-established and disclosed standards, to satisfy the customers and in the offer of products with characteristics not available by the competitors. From this, allowing only certain vehicle models with certain colors and a maximum of five years of manufacturing contribute to the quality of the fleet.

When respondents were questioned about how customers saw this differential and what the relationship with the "quality" competitive priority was, it was noted that at least half of the products users choose these options and the company believes they are very relevant to increase the quality of service perceived by the customer. In addition, as they are unique characteristics of the company, was highlighted as a factor that reinforces the competitive priority "quality" in the company.

The coordinator believes that the possibility of customization differentiates the service and makes it better than the one offered by the competitors. So "quality" as a competitive priority is being practiced in this aspect. For the associate 1 , the personalization of the service makes it unique in the market and enables it to meet a more demanding market share. Associate 2 also corroborates this view, with the perspectives that passengers, primarily corporate, require more quality, and for this reason, the company must always seek to offer new products in order to exceed customer expectations.

Regarding the possibility of making rapid changes in the service offered, there was unanimity among the interviewees about the need for such action. For the manager of the unit studied, it is possible to make changes to the application, change payment method and modify 
priorities in the travel queue. The unit's coordinator also raised other points, such as the practice of lower prices and the introduction of new vehicle categories.

The associate 1 has raised some improvements that can be made, such as improvement in the search system by driver and the most appropriate pricing taking into consideration other variables, such as neighborhood and time. Relating these answers to the competitive priority adopted by the company, it is realized that it is possible to perform a service with higher quality through innovation in the product mix.

According to the interviewees, increasing the mix of products is good so that customers can have access to several types of service in a single application. For the market, the company can improve its image by becoming known in several segments.

On the other hand, as a negative point, the company may lose focus and the trade-offs involved in the possibility of expanding the product offered need to be analyzed. Even more so than the fact that there is unanimity that the delivery time of the company is higher than the competitors' time. Even if the competitive priority "quality" is practiced and the company adopts a premium price for a high quality compared to the market, the price of the service must be within the limits acceptable to the market. Discounts are granted through vouchers.

\subsection{Quality and innovation}

Although the analyzed company adopts "quality" as a competitive priority, there is no Structured Quality Management System, as it does not have certifications associated. From the interviews it was noticed that the quality of the service is thought and practiced in a punctual and analytical way, without the use of quality methods and tools.

There is a concern with quality in the areas of Logistics and Sales, which follow certain procedures to maintain it to the user base and drivers, using this, from the evaluations. To measure the performance of the service, certain indicators are used and table 2 presents the main indicators according to the opinion of the interviewees. 
Table 2 - Main quality indicators according to interviewees.

\begin{tabular}{c|c|c|c|c} 
IndicatorInterviewer & $\begin{array}{c}\text { Logistics } \\
\text { Manager }\end{array}$ & $\begin{array}{c}\text { Logistics } \\
\text { Coordinator }\end{array}$ & $\begin{array}{c}\text { Logistics } \\
\text { Associate 1 }\end{array}$ & $\begin{array}{c}\text { Logistics } \\
\text { Associate 2 }\end{array}$ \\
\hline Delivery fee & $\mathrm{X}$ & $\mathrm{X}$ & $\mathrm{X}$ & $\mathrm{X}$ \\
\hline Customer rating & & $\mathrm{X}$ & $\mathrm{X}$ & $\mathrm{X}$ \\
\hline Driver rating & & $\mathrm{X}$ & & $\mathrm{X}$ \\
\hline Waiting time & $\mathrm{X}$ & & $\mathrm{X}$ & \\
\hline Fraudulent travel rate & & $\mathrm{X}$ & & \\
\hline Average trip evaluation & $\mathrm{X}$ & & & $\mathrm{X}$
\end{tabular}
Source: Prepared by the authors.

The evaluation of drivers and passengers is done through the app. At the end of each trip, each of them evaluates the other. In this way, it is possible to maintain the quality of the customer base for drivers and passengers.

Any type of problem or non-compliance can be reported by the app through the evaluation field and you can also use a call center that works 24 hours a day for 7 days a week. There are other means of communication in which the customer can use to get in touch with the company such as chat, email and social networks. This support can be seen as a quality after-sales service guarantee.

Quality plays an important role in the generation of innovations in services, as demonstrated by Carvalho and Paladini (2013). In addition, Oliveira (2003) complements that it is the competitors that dictate what the level of quality practiced by the company should be and that it is the customers that determine if this level of quality satisfies them. These evidences are observed in the company researched, both in the sphere of market, as in the sphere of clients.

In relation to the market, in order to reinforce the quality of the service offered, the personalization of the service is adopted as a competitive differential. That is, to position itself above the competitors in the quality aspect, the company allows the customer to customize their service with up to three items, a factor of innovation in this market.

As for customers, they evaluate the service purchased and present feedback to the company reporting the degree of satisfaction. In this way, the company can raise points of improvement and betterment of the service, as analyzed by Heizer and Render (2001) and generate innovation from this information.

It is important to emphasize that the quality of the service perceived by the client involves the results of its interaction with the environment, the service provider and the 
process. In the researched company, it was observed that these three factors are fundamental to provide a service of quality and innovation, essential elements for the competitiveness of a company, pointed out by Carvalho and Paladini (2013) and Weckenmann et al. (2015). These factors have manifested themselves in the form of the vehicle, the driver and all other standard or customizable processes that involve customer satisfaction during the journey.

In this sense, it is perceived that quality is defined as a strategic priority for the company and is transmitted in this way, contributing to the generation of innovation, reinforcing classic approaches such as Bettencourt et al. (2013), Snyder, Witell, Gustafsson et al. (2016), Witell, Snyder, Gustafsson et al. (2016) and Ryu and Lee (2018) that the generation of product innovation associated with services has been improved to promote competitive advantage over competitors, but quality is not assumed and manifested in full conformity with the definition framework, implying a pragmatic performance.

Finally, together with the perception of the research results, it is important to note that technological innovation observed in this company does the mobilization of internal or external skills and tangible or intangible techniques to produce as final characteristics of the product in question as an element of differentiation and benefits. Table 3 presents a summary of the main research results.

Table 3 - Main research results.

\begin{tabular}{l|l} 
Main observations & characteristics \\
\hline Main product & services in urban mobility \\
\hline Profile of clients & women of social class A and B \\
\hline Service providers, drivers & $\begin{array}{l}\text { unemployed or seeking an alternative source of income } \\
\text { and belong to classes C and D }\end{array}$ \\
\hline Main competitive priority & quality \\
\hline Determining quality & $\begin{array}{l}\text { shared, logistics area responsible for conducting the } \\
\text { training and the driver is the one who has a high degree } \\
\text { of contact with the customer }\end{array}$ \\
\hline $\begin{array}{l}\text { only certain vehicle models with certain colors and a } \\
\text { maximum of five years of manufacturing } \\
\text { possibility of customization of services } \\
\text { it is possible to make changes to the application, } \\
\text { change payment method and modify priorities in the } \\
\text { travel queue } \\
\text { a call center that works 24 hours a day for 7 days a } \\
\text { week }\end{array}$ \\
\hline $\begin{array}{l}\text { Quality management } \\
\text { limitations }\end{array}$ \\
it does not have certifications associated
\end{tabular}

Source: Prepared by the authors. 


\section{CONCLUSION}

The aim of the study was to identify the competitive priority (s) and analyze practices and strategies adopted regarding quality management that reinforce the priority (s) practiced in a given organization and the potentialities of the decisions taken in terms of these priorities.

From the results achieved, it can be noted that among the four competitive priorities seen in the literature - cost, quality, delivery and flexibility - the main priority adopted by the company is "quality". However, it is noted that there is no structured quality management, only indicators are used to measure the performance of the service and punctual activities are performed to maintain the quality of the service. However, as a means of encouraging the competitive priority adopted there are several practices that promote service delivery as a quality experience.

If customers determine whether a service is acceptable or not, it is up to the company to demand and maintain that level of quality of service. In addition, the company has a demanding target audience which, corroborating the literature, requires high quality levels and a great dynamism in launching new service options.

In this sense, the company directs its time and resource efforts to strengthen the "quality" priority adopted. Despite the fact that the other priorities are in the background, the company has set up and seeks to conduct its strategies from the perspective of other competitive priorities acting in a way that has a minimum satisfactory performance.

Based on the results, it was possible to observe that the technologies for mobility allows the implementation of innovation based on the perception of the customer's desire, which, in the case of this research, had quality is the central element to guide its competitors. A central point identified was the fact that the company under study used innovation when customizing products to maintain competitive levels of quality and differentiation through service innovations. On the other hand, as identified in the research, there is a restriction with a greater impact, which is the fact of the difficulty in controlling the levels of services performed by drivers.

Although this finding allows researchers to identify certain traits of service innovation, on the other hand it hampers theoretical development, since it does not explain why some new services become successful and others do not. Different perspectives of innovation in services can explain the content and emergence of different types of innovations. Therefore, in this 
sense, organizations need to balance competitive priorities in their innovation efforts. In this sense, the research contributes to a better understanding of customer needs, greater customer satisfaction, and better-quality service delivery, resulting in performance and competitive advantage for the company.

In addition, another research contribution focuses on an emerging topic in the literature, starting with a service company in the urban mobility segment to relate Competitive Priorities, Quality Management and Innovation, within a context of a model of dynamic and contemporary business.

By means of the results obtained, it is evident the importance that the competitive priority "quality" brought to the company in terms of differentiation in relation to the other competitors and as a driving force in the generation of incremental innovations of new products offered to its customers. On the other hand, the absence of structured Quality Management contributes to actions that are timely and without the perspective of long-term actions.

\section{References}

ALVES FILHO, A.; PIRES, S.; VANALLE, R. Sobre as prioridades competitivas da produção: compatibilidades e sequências de implementação. Gestão \& Produção, v. 2, n. 2, p. 173-180, 1995.

BETTENCOURT, L.; BROWN, S.; SIRIANNI, N. The secret to true service innovation. Business Horizons, v. 56, p. 13-22, 2013.

BOURANTA, N.; PSOMAS, E. A comparative analysis of competitive priorities and business performance between manufacturing and service firms. International Journal of Productivity and Performance Management. v. 66, n. 7, p. 914-931, 2017.

BOYER, K.; LEWIS, M. Competitive priorities: investigating the need for trade-offs in operations strategy. Production and operations management, v. 11, n. 1, p. 9-20, 2002.

CAI, S.; YANG, Z. On the relationship between business environment and competitive priorities: The role of performance frontiers. International Journal of Production Economics, v. 151, p. 131-145, 2014.

CARVALHO, M.; PALADINI, E. Gestão da qualidade: teoria e casos. Elsevier Brasil, 2013. 
DANGAYACH, G.; DESHMUKH, S. An exploratory study of manufacturing strategy practices of machinery manufacturing companies in India. Omega, v. 34, n. 3, p. 254-273, 2006.

DÍAZ-GARRIDO, E.; MARTÍN-PEÑA, M.; SANCHEZ-LÓPEZ, J. Competitive priorities in operations: development of an indicator of strategic position. CIRP: Journal of Manufacturing Science and Technology, v. 4, p. 118-125, 2011.

FONSECA, J. Metodologia da Pesquisa Científica. Fortaleza: UEC, 2002.

GARTNER, I.; GARCIA, F. Criação de valor e estratégia de operações: um estudo do setor químico e petroquímico brasileiro. Gestão \& Produção, v. 12, n. 3, p. 459-468, 2005.

GROBLER, A.; GRUBNER, A. An empirical model of the relationships between manufacturing capabilities. International Journal of Operations \& Production Management, v. 26, n. 5, p. 458-485, 2006.

HAYES, R.; PISANO, G.; UPTON, D.; WHEELWRIGHT, S. Estratégias de Produção: Origens e novas orientações. In: Produção, estratégia e tecnologia: em busca da vantagem competitiva. Porto Alegre: Bookman, p.57-94. 2008.

HEIZER, J.; RENDER, B. Estratégia de operações para obtenção de vantagem competitiva. In: Administração de operações: bens e serviços. LTC, p.25-35, 2001.

HUNG, S.; HUNG, S.; LIN, M. Are alliances a panacea for SMEs? The achievement of competitive priorities and firm performance. Total Quality Management and Business Excellence. v. 26, n. 1, 190-202, 2014.

JABBOUR, A. Prioridades competitivas da produção e práticas de gestão da cadeia de suprimentos: uma survey no setor eletroeletrônico brasileiro. Tese (Doutorado em Engenharia de Produção) - Universidade Federal de São Carlos, 2010.

JAYARAM, J.; XU, K. Determinants of quality and efficiency performance in service operations. International Journal of Operations \& Production Management, v. 36, n. 3, p. $265-285,2016$.

KATHURIA, R.; PORTH, S.; KATHURIA, N.; KOHLI, T. Competitive priorities and strategic consensus in emerging economies: evidence from India. International Journal of Operations \& Production Management, v. 30, n. 8, p. 879-896, 2010.

KATHURIA, R.; KATHURIA, N.; KATHURIA, A. Mutually supportive or trade-offs: An analysis of competitive priorities in the emerging economy of India. The Journal of High Technology Management Research, v. 29, p. 227-236, 2018.

KRAMMER, M. S. Science, technology, and innovation for economic competitiveness: The role of smart specialization in less-developed countries. Technological Forecasting and Social Change, v. 123, p. 95-107, 2017. 
LIN, Y.; TSENG, M. Assessing the competitive priorities within sustainable supply chain management under uncertainty. Journal of Cleaner Production, v. 112, p. 2133-2144, 2016.

MAIA, J.; CERRA, A.; ALVES FIHO, A.; OLIVEIRA, G. Trajetórias da Estratégia de Operações: um estudo longitudinal em uma montadora de motores para automóveis instalada no Brasil. GEPROS: Gestão da Produção, Operações e Sistemas, v. 4, n. 3, p. 61, 2009.

MIGUEL, P. A. C. Estudo de caso na engenharia de produção: estruturação e recomendações para sua condução. Production, v. 17, n. 1, p. 216-229, 2007.

MIGUEL, P. A. C. Qualidade: Enfoques e Ferramentas. In: Qualidade em serviços. Artliber Editora, p.43-68, 2012.

MIKAMI, K. Are cooperative firms a less competitive form of business? Production efficiency and financial viability of cooperative firms with tradable membership shares. Economic Systems, v. 42, p. 487-502, 2018.

MIRANDA, A.; GALLOTTI, M.; MIRANDA, E. A gestão da qualidade como estratégia de suporte para o desenvolvimento de coleções em bibliotecas jurídicas. RDBCI: Revista Digital de Biblioteconomia e Ciência da Informação, v. 14, n. 2, p. 262-278, 2016.

OLIVEIRA, O. Gestão da Qualidade: Introdução à história e fundamentos. In: Gestão da Qualidade-Tópicos Avançados. Cengage Learning Editores, p.3-20, 2003.

PRAJOGO, D. I., MCDERMOTT, P. Examining competitive priorities and competitive advantage in service organisations using importance-performance analysis matrix. Managing Service Quality, v. 21 n. 5, p. 465-483, 2011.

ROY, S.; SREEJESH, S.; BHATIA, S. Service quality versus service experience: An empirical examination of the consequential effects in B2B services. Industrial Marketing Management, v. 82, p. 52-69, 2019.

RYU, H.; LEE, J. Understanding the role of technology in service innovation: Comparison of three theoretical perspectives. Information \& Management, v. 55, p. 294-307, 2018.

SCUR, G.; HEINZ, G. A Dimensão Ambiental no Contexto da Estratégia de Operações de Montadoras do ABC Paulista. Revista Brasileira de Gestão de Negócios, v. 18, n. 60, p. 290-304, 2016.

SCHIAVONE, F.; PAOLONE, F.; MANCINI, D. Business model innovation for urban smartization. Technological Forecasting and Social Change, v. 142, p. 210-219, 2019.

SILVA, E. M.; SANTOS, F. C. A; CASTRO, M. Análise das relações entre estratégia de produção, práticas e desempenho operacional. Production, v. 22, n. 3, p. 502-516, 2012.

SLACK, N.; LEWIS, M. Operations Strategy. New York: Prentice Hall, 2008. 
SNYDER, H.; WITELL, L.; GUSTAFSSON, A.; FOMBELLE, P.; KRISTENSSON, P. Identifying categories of service innovation: A review and synthesis of the literature. Journal of Business Research, v. 69, p. 2401-2408, 2016.

SWINK, M.; WAY, M. H. Manufacturing strategy: propositions, current research, renewed directions. International Journal of Operations \& Production Management, v. 15, n. 7, p. 4-26, 1995.

THEODOROU, P.; FLOROU, G. Manufacturing strategies and financial performance - the effect of advanced information technology: CAD/CAM systems. Omega, v. 36, n. 1, p. 107$121,2008$.

VOSS, C. Alternative paradigms for manufacturing strategy. International Journal of Operations \& Production Management, v. 15, n. 4, p. 5-16, 1995.

VOSS, C. Alternative paradigms for manufacturing strategy. International Journal of Operations \& Production Management, v. 25, n. 12, p. 1211-1222, 2005.

WARD, P.; McCREERY, J.; ANAND, G. Business strategies and manufacturing decisions: An empirical examination of linkages. International Journal of Operations \& Production Management, v. 27, n. 9, p. 951-973, 2007.

WECKENMANN A.; AKKASOGLU G.; WERNER T. Quality management - history and trends, The TQM Journal, v. 27, n. 3, p. 281-293, 2015.

WITELL, L.; SNYDER, H.; GUSTAFSSON, A.; FOMBELLE, P.; KRISTENSSON, P. Defining service innovation: A review and synthesis. Journal of Business Research, v. 69, p. 2863-2872, 2016.

YIN, R. Estudo de caso: planejamento e métodos. Porto Alegre: Bookman, 2001. 